\title{
Comparison of Vocational Education between China and Foreign Countries and Its Enlightenment to China 's Vocational Education
}

\author{
ZOU Hongyan ${ }^{1}$, YANG Xiaofeng ${ }^{2}$
}

${ }^{1.2}$ Kunming Vocational and Technical College of Industry, Kunming 650302, Yunnan, China a44032652@qq.com, b759683550@qq.com

Keywords: vocational education; training mode; school - enterprise cooperation

\begin{abstract}
The development of vocational colleges in our country is in the critical period from large-scale to characteristic and connotation construction. The paper compares the higher vocational education system of Germany and the other countries, such as the mode of talent training mode, course mode, education teaching mode and ideas.
\end{abstract}

\section{中外职业教育比较及对我国职业教育的启示 \\ 邹红艳 ${ }^{1 *}$,杨晓峰 ${ }^{2}$ \\ 1, 2 昆明工业职业技术学院, 昆明, 云南, 中国 \\ a44032652@qq.com, b759683550@qq.com}

关键词：高职教育；培养模式；校企合作.

摘 要 我国高职院校发展正处于由规模化向特色、内涵建设的关键时期。论文从高职院校办学模式、 人才培养模式、课程模式、教育教学模式等方面, 与德国等国外高职教育体制较为完善的国家进行比 较, 寻求适应我国高职院校发展的新模式、新思路。

\section{1.引言}

从上世纪 80 年代至今, 我国高职院校经历了 30 余年的快速发展, 发展模式从最初的规 模化发展, 逐渐向特色发展、内涵建设转变, 培养出了一批能够从事生产、服务和管理的面 向社会服务的高层次实用型、技能型人才。截止 2015 年 8 月, 我国共有高职院校 1334 所, 在校生达到 1420 万人。在专业设置上, 分为 19 个专业大类, 合计 747 个专业。通过推动专 业设置与产业需求对接, 课程内容与职业标准对接, 教学过程与生产过程对接, 毕业证书与 职业资格证书对接, 职业教育与终身学习对接, 促进高等职业教育更好地服务经济社会发展 和人的全面发展。

\section{1. 中外职业教育发展的共同规律和特点}

\section{1 职业教育是推进经济发展的决定性力量}

从国际上来看，职业教育的发展程度及普及状况是衡量一个国家现代化程度和社会文明 程度的一个重要标志。通常发达国家都有完善的职业教育体系和成熟的职业教育模式。如德 国的 “双元制”、美国的社区学院、加拿大的 CBE、澳大利亚的 TAFE。特别是德国人创造的 学校教育与企业培训紧密结合, 以企业培训为主的 “双元制” 职业教育, 不仅为其战后的崛 
起起到了强大的推动作用，而且构成了德国民族文化的一个重要方面。

\section{2 技术进步是职业教育发展的根本动力}

一般讲，职业教育是工业化的产物，但从本质上看，职业教育是科技进步的结果。从 18 世纪末蒸汽机的发明，引发了第一次工业革命。随着世界范围内新技术革命的兴起，工业发 展从工业 1.0、2.0、3.0 到工业 4.0, 新工业革命的核心是智能化、网络化、大数据分析, 从世界趋势看, 工业发展已进入信息化时代。新工业革命加速推进机器人等智能设备的应用, 带来了经济结构和劳动力就业结构的变化, 新的产业和职业不断出现, 对培养新生劳动力的 职业教育提出了要求, 同时也带来了职业教育由中等层次向高等层次上移的发展趋势, 社会 对技术型人才的需求日趋旺盛，对技术技能型人才职业能力的要求不断提高。

\section{3 学习和借鉴是促进职业教育发展的重要环节}

第一次世界大战前的世界博览会, 是各发达国家经济和技术交流的重要场所。1851 年伦 敦举办了国际博览会, 博览会后, 英国政府和工商界提高了对职业教育的认识并采取了一些 相应的措施：设立科学与工艺署掌管职业教育, 建立皇家技术教育委员会研究对策, 制定法 律支持职业教育。博览会的举行极大地推动了职业教育的发展, 每次博览会上都能看到法国、 德国、瑞士等国向世界展示出的优秀技术。日本是一个勇于和善于借鉴外国教育经验的国家, 尤其是近代的日本，更是通过 “明治维新” 借鉴和学习了西方发达资本主义国家的职业教育 的经验和教训, 并努力提高到欧洲列强的水平。近代日本对欧美职业教育的借鉴, 大致呈现 了一个由 “移植与模仿” 阶段到 “消化与自立” 阶段, 再到 “吸收与创新” 阶段的逐渐成熟 的过程。但比起美国, 日本对他国经验的模仿多于创新。

\section{4 职业教育面向大众是推进教育普及的主要途径}

职业教育从产生那天起, 就是主要面向工农群众的一个教育类型, 职业教育在推进教育 民主使教育成为广大人民群众都能享有的最基本权利的进程中, 发挥了不可替代的作用。“二 战” 以后发达国家都着手恢复或重建本国的教育制度, 开展了更深更广的教育改革。战后各 国领导者纷纷将扩大教育规模和普及中等教育作为主要目标。中等职业技术教育作为中等教 育的一个组成部分, 得到了社会的广泛认同。中等职业教育伴随着中等教育的发展而发展, 同时, 中等职业教育在发展中也逐步成为普及中等教育的重要力量。各发达国家在发展中等 教育中, 都注意加强职业教育, 以满足不同青年的多样化需求。目前, 职业教育已成为许多 发达国家高中阶段教育的主体。

\section{5 产教结合是成功职业教育模式的共同特征}

德国双元制、加拿大 CBE 模式、澳大利亚 TAFE 模式的一个共同特征就是产教结合。现代 职业教育是由传统的学徒制演进而来的, 体现了职业教育的进步与发展。但学校职业教育有 许多自身难以克服的缺陷。正如石伟平教授曾经提出的：无论教学内容如何先进，与生产、 服务第一线所应用的最新技术、最新工艺相比, 总有距离; 无论教学设备如何先进, 与工业 企业的最新机器、最新生产线相比, 总有距离; 无论学校的专业教师技能水平如何高, 与生 产一线的技术专家、操作能手相比，总有距离。只有通过产教结合才能解决这些问题。

\section{6 职业教育的内涵不断拓展，呈多样化、终身化趋势}

“职业教育”多数情况下，是指培养一般熟练工人或半熟练工人的职业教育和培训; 高一 层次的“职业教育”通常称之为“技术教育”，即以培养一般的技术人员为主要目标; 再高层次 的“职业教育”便是那种以培养工程师或高级专业技术人员为目标的“专业教育”。1974 年联合 国教科文组织曾建议将“职业和技术教育”作为教育的综合性术语，1984 年该组织出版了《技 术和职业教育术语》一书，并对技术教育与职业教育加以区别：职业教育“通常在中等教育后 期进行”，“通常着重于实际训练”，培养“技能人员”; 技术教育则是“设置在中等教育后期或 
第三级教育（高中后教育）初期，以培养中等水平人员（技术员、中级管理人员等）以及大 学水平的工程师和技术师。1999 年 4 月联合国教科文组织又使用了“技术和职业教育与培 训”(TVET)的概念。近年来, 联合国教科文组织、国际劳工组织、世界银行、亚洲开发银行 等国际机构越来越普遍地使用技术和职业教育与培训(TVET)的术语，用以替代传统的职业技 术教育或职业教育。TVET 包括以下内容：普通教育中的技术和职业入门教育; 为从事某种 职业做准备的技术和职业教育; 作为继续教育组成部分的技术和职业教育。在终身学习制度 的框架下，学习者的年龄、身份等差距在逐渐淡化，职业教育的短期性、技能性和社区性的 特点愈加凸显, 职业教育将进一步与成人教育相互融合。

\section{2. 办学模式比较}

我国高职教育以公办为主，但已开始打破政府一家独办的传统格局，逐渐出现了多体制 办学的良好态势。

美国社区学院的突出特点是办学体制灵活，充分满足当地社会各类人员的需求，为当地 的经济发展做出了贡献。美国的社区学院由所在州及当地政府领导和管理, 州政府设有高等 教育委员会和社区学院委员会, 委员会与各学院无行政隶属关系, 不干预学院具体办学。社 区学院设有董事会和执委会, 学院院长由董事会选聘, 董事会由当地名流及各行业代表组成。

德国的高职教育办学体制与企业紧密相关。职业学院都成立理事会(董事会)，该组织来 自出资企业的代表, 主要监督学校经费使用情况。正是有了企业的鼎力相助, 德国高等职业 教育的发展才兴旺发达。企业为培养一名职业学院的学生要花费 5-8 万马克费用, 但企业仍 把此看作是一种经济实用的获取人才的措施。

英国采取一种开放的高职办学体制。英国的技术员、工程师培养都以“课程计划”或 “培 训方案” 为中介。英国用 “国家职业资格 NVQ” 的制度来培养不同层次的职业人才; NVQ 考试课程中的第二、第三级为 “中职” 课程, 第四、第五级为 “高职” 课程。这样, 凡是有 条件提供此课程的学校或培训机构, 都可向主管部门申请; 一旦鉴定后被认可, 便有资格开 设这类课程。无论是作为中等教育机构的 “继续教育学院” ，还是作为高教机构的 “工程技 术大学” ，都设有这种不同层次的职教课程。主管部门只管办学资格的审核、课程标准的制 定与培训结果的考核。英国这种高职教育办学体制与管理体制上的 “开放型” 与 “灵活性” , 很值得我们借鉴。

日本职业技术教育体制的一大特色是企业办学。日本的高职学院 $80 \%$ 以上为私立，与 中国高职院校的约 $80 \%$ 一以上为公办(国家及地方)刚好相反。大企业兴办的 “工学院” 既为 自己培养急需的专门技术人才, 也为客户提供技术培训。在企业技能培训与学院教学时间的 分配上, 明显以企业为主、学校为辅, 而且学校的教学多半是利用工余时间, 其特点是重视 科学研究方面的合作。毕业学生由企业消化。

\section{3. 培养目标}

我国普通高等教育培养的是研究型和探索型人才以及设计型人才，这类人才对于国家未 来发展的现代化建设无疑是十分重要的。高等职业教育就是既具有大学程度的专业知识, 又 具有高级技艺、善于将工程图纸化为物质实体，并能在现场进行技术指导和管理的技术人才 和管理人才。或者说, 高等职业技术教育培养的是技艺型、操作型、具有大学文化层次的高 级技术人才。

美国社区学院高等职业教育人才培养目标，主要面向社区，社区内需要什么人就培养什 么人, 公民想学什么专业就开设什么专业, 学院设施全部向当地公民开放, 完全为社区发展 服务。

德国高等职业教育的培养目标非常明确, 那就是培养应用型人才, 特别是职业学院, 它 
不是为自由的劳动力市场培养 “通用人才” ，而是为特定的企业培养 “专用人才” ，使学生 既在企业里接受职业技能培训, 又有部分时间在职业学校接受专业理论和普通文化知识, 将 企业与学校、理论与实践紧密结合起来, 主要培养专业技术工人, 所培养的学生具有针对性, 毕业后可以直接上岗。

英国多数技术学院的高职教育人才培养完全是根据当地的工业、商业、服务业的实际需 要而确定的, 需要什么样的人才, 事先要多次调查, 反复征询有关企事业单位意见, 然后进 行评价，再报地方委员会批准。

日本的高等职业教育，根据社会经济发展的技术人才需要进行培养，坚持自身特色，办 学和人才培养目标明确, 针对性强, 除了大专层次外, 科学技术大学还实施本科和研究生(硕 士、博士)教育。

\section{4. 结论}

纵观世界范围，受生产力水平、产业结构、社会发展目标、意识形态和政治制度等诸多 因素的影响, 各国高职教育都具备其鲜明办学特色, 并赢得了社会的广泛认可, 成为各国高 等教育结构中不可缺少的组成部分。通过对国外高职教育培养模式的研究, 结合我国实际情 况可得出如下启示:

(1) 高职教育职业能力培养应具有导向性

我国高职院校的专业人才培养能力应当适应职业的变化。当前企业对某一类人才或职业 技能的需求会因技术条件及市场的变化而改变, 只有适应企业人才的需求，才能使高职毕业 生得到社会和用人单位的认可。

(2) 高职教育职业能力培养的目标应当多样化

高职教育职业能力培养目标多样化主要体现在岗位需求的多变性，如 “技能型人才”、 “技术性人才”、“应用技术性人才” 等。这就要求高职院校各专业应根据生产、建设、管 理、服务一线的实际需求和专业特点确定培养目标。

(3) 高职教育职业能力培养的主体多元化

高职教育仅仅依靠学校进行能力培养是远远不够的, 还必须引进社会资源参与人才培养, 多元化有利于实现人才培养与社会就业的有效衔接。此外, 还应坚持学校和行业、专业团体 及企事业用人单位共同商定的原则，确立符合社会需要的人才培养目标和人才规格。

\section{References}

[1] HY Liu,YX Gai and XU Ning,Exploration of CDIO Model for Engineering Education in China,Research \& Exploration in Laboratory[J],pp.13-19, 2011.

[2] LF Wang,MT Wang and JY Huang,A Comparative Study of Higher Vocational Talents Training Models with China and other countries.Journal of Yuncheng University[J], pp.22-24,2010(6).

[3] Pilz,M. Why Abiturienten do an apprenticeship before going to university:the role of double qualifications'in Germany [J].Oxford Review of Education,2009, 35(2):187-2014 